\title{
Analisis Kadar Besi, Feritin, dan Transferin pada Ibu Hamil Kurang Energi Kalori
}

\author{
Rahajoe Imam Santosa, Salmon Charles Siahaan, Ihyan Amri, Natalia Yuwono \\ Fakultas Kedokteran Universitas Ciputra, Surabaya, Indonesia \\ Alamat Korespondensi: charles.siahaan@ciputra.ac.id
}

\begin{abstract}
Abstrak
Ibu hamil dengan kurang energi kalori (KEK) merupakan kondisi yang berhubungan antara asupan energi dan nutrisi yang tidak mencukupi sebelum dan selama kehamilan. Berdasarkan RISKESDAS (Riset Kesehatan Dasar) tahun 2018 prevalensi perempuan usia subur (15-49 tahun) ibu hamil dan mengalami risiko KEK di Jawa Timur 27,6\%. Penelitian ini bertujuan untuk mengetahui perbedaan kadar serum iron, transferin, dan feritin pada ibu hamil normal dengan ibu hamil KEK pada trimester kedua. Penelitian ini menggunakan uji analitik yang bersifat case control dengan randomisasi terhadap pasien ibu hamil dan ibu hamil dengan kurang energi kalori (KEK) pada Kecamatan Sukomanunggal. Hasil penelitian didapatkan perbedaan iron pada hamil normal dengan hamil KEK $(101,30 \pm 40,155$ vs $107,00 \pm 33,686)$ nilai $p=0,710$ menunjukkan perbedaan tidak bermakna. Perbedaan feritin pada hamil normal dengan hamil KEK $(21,5025 \pm 14,40025$ vs $26,4558 \pm$ 23,63288 ) nilai $\mathrm{p}=0,542$ menunjukkan perbedaan tidak bermakna. Perbedaan transferin pada hamil normal dengan hamil KEK $(419,17 \pm 86,755$ vs $458,83 \pm 68,816)$ nilai $\mathrm{p}=0,228$ menunjukkan perbedaan tidak bermakna.
\end{abstract}

Kata Kunci: feritin, hamil, iron, transferin

\section{Analysis of Serum Iron and Transferrin Levels in Pregnant Women with Low Calorie Energy}

\begin{abstract}
Pregnant women with chonic energy deficiency (CED) is a condition associated with insufficient energy and nutrient intake before and during pregnancy. Based on RISKESDAS in 2018 the prevalence of women of childbearing age (15-49 years) which is pregnant and experiencing the risk of CED in East Java was 27,6. This study aims to determine differences in serum iron levels, transferrin and ferritin in normal pregnant women with low calorie energy (LCE) pregnant women in the second trimester. This study uses an analytical test that is case control with randomization of pregnant women and pregnant women with LCE in Sukamanunggal sub-district. The results showed that the difference in iron in normal pregnancy with CED pregnant $(101,30 \pm 40,155 \mathrm{vs}$ 107,00 $\pm 33,686)$ p value 0,710 showed no significant difference. The difference between ferritin in normal pregnancy and CED pregnancy $(21,5025 \pm 14,40025 v s$. 26,4558 $\pm 23,63288) p$ value $=0,542$ showed no significant difference. The difference between transferrin in normal pregnancy and CED pregnancy $(419,17 \pm 86,755 \mathrm{vs} .458,83 \pm 68,816)$ p value 0,228 showed no significant difference.
\end{abstract}

Keywords: chronic energy deficiency, ferritin, iron, pregnant, transferin

\section{Pendahuluan}

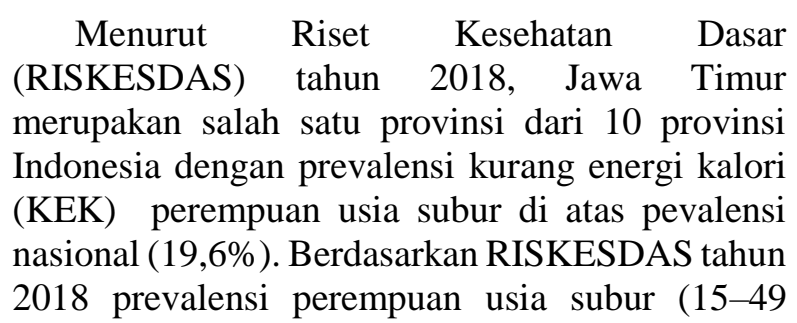

tahun) ibu hamil dan mengalami risiko KEK di Indonesia 27,6\%, sedangkan data nasional prevalensi penduduk perempuan usia subur yang sedang hamil dan mengalami risiko KEK sebesar $26,8 \%{ }^{1}$

Ibu hamil dengan kurang energi kalori (KEK) adalah suatu kondisi di mana asupan energi dan nutrisi yang tidak mencukupi pada saat sebelum dan selama kehamilan pada beberapa ibu hamil. 
Kesadaran akan kebutuhan nutrisi perempuan sangat penting tanpa menunggu seorang perempuan hamil. Kondisi berat badan rendah sebelum kehamilan akan memengaruhi kondisi luaran bayi pada kehamilannya termasuk pada kemampuan intelegensia dari seorang bayi dan kelahiran preterm yang berulang. ${ }^{2-5}$

Perempuan dengan malnutrisi pada saat sebelum hamil atau selama minggu pertama kehamilan cenderung melahirkan bayi dengan kerusakan otak dan sumsum tulang akibat gangguan pembentukan sistem saraf pusat yang sangat peka pada $2-5$ minggu pertama. Jika ibu menderita malnutrisi hingga minggu terakhir kehamilan, maka ibu berisiko melahirkan bayi dengan berat badan lahir rendah $(<2500$ gram). Kenaikan berat badan ibu hamil yang tidak signifikan juga akan memengaruhi luaran bayi. Penentuan kategori ibu hamil dengan kurang energi kalori menggunakan pengukuran lingkar lengan atas, di mana kurang dari 23,5 dikategorikan menjadi ibu hamil dengan kek. 1,6-8

Anemia defisiensi zat besi (Iron Deficiency Anemia / IDA) selama kehamilan menyebabkan efek samping yang serius, seperti ketuban pecah dini, infeksi nifas, restriksi pertumbuhan janin, hipoksia janin, dan kelahiran prematur. Selama kehamilan terjadi peningkatan kebutuhan yang signifikan atas kebutuhan zat besi untuk meningkatkan massa sel darah merah, memperbesar volume plasma, dan untuk memungkinkan pertumbuhan unit feto-plasenta. Pada perempuan hamil yang tidak diberikan zat besi tambahan, konsentrasi hemoglobin $(\mathrm{Hb})$ darah ibu dapat turun dari rata-rata, selain itu serum feritin dan serum transferin juga mengalami perubahan sehingga berpotensi menyebabkan anemia defisiensi besi. ${ }^{9}$

Hepsidin menjadi indikator defisiensi zat besi yang efektif pada kehamilan, karena merupakan hormon pengatur zat besi yang diproduksi oleh hati dan mampu mengontrol konsentrasi zat besi pada plasma serta distribusinya pada jaringan. Selama kehamilan dan saat persalinan, konsentrasi hepsidin ibu berkolerasi positif dengan serum ferritin (SF), namun saturasi transferin (Transferrin Serum /TSAT) yang berkolerasi terbalik dengan reseptor transferin terlarut (sTfR) dan hemoglobin. Setelah persalinan, konsentrasi serum hepsidin mengalami peningkatan mungkin akibat adanya perubahan fisiologis yang berhubungan dengan persalinan tetapi tidak berkorelasi dengan konsentrasi serum ferritin (SF). Menurut penelitian terbaru dari Amerika Serikat menunjukkan bahwa defisiensi zat besi menunjukkan serum feritin rendah $(<30 \mu \mathrm{g} / \mathrm{L})$ dan saturasi transferin rendah $(<19 \mathrm{mg} / \mathrm{dL}) .{ }^{11-13}$

Serum feritin dan serum transferrin digunakan sebagai indikator perubahan dalam tubuh, karena penurunan zat besi dari tingkat normal ke tingkatan anemia defisiensi besi. Feritin serum rendah (< $15 \mu \mathrm{g} / \mathrm{L}$ ) menunjukkan terkurasnya simpanan zat besi dalam tubuh, dan peningkatan serum transferin yang mencerminkan defisiensi zat besi fungsional atau keadaan eritropoiesis defisiensi zat besi. Hal ini diperkuat dengan penelitian terbaru dari Siahaan (2021) yang menyatakan bahwa terdapat hubungan antara penurunan lingkar lengan atas (LILA) dengan terjadinya penuruhan $\mathrm{Hb}$ pada ibu hamil kurang energi kronis. Penelitian Hendera (2021) menyebutkan bahwa ibu hamil KEK berhubungan dengan kejadian anemia akibat defisiensi ferritin. ${ }^{14-16}$

Pengaruh tiga tingkatan anemia (normal, ringan, dan sedang / berat) dan Body Mass Index / BMI (berat badan kurang, normal, dan kelebihan berat badan / obesitas) dinilai pada tingkat cara persalinan, komplikasi terkait kehamilan saat melahirkan, dan pasca persalinan. Ditemukan > 90\% ibu hamil menderita anemia, 35\% kekurangan berat badan (BMI <18,5) dan hampir sepertiga mengalami kedua kondisi tersebut. Kebanyakan perempuan mengalami anemia ringan-sedang, dengan anemia berat kurang dari $0,2 \%$ sedangkan anemia ringan sebelum 20 minggu kehamilan tidak meningkatkan risiko lahir mati, kematian neonatal atau BBLR, peningkatan risiko lahir mati dan kematian neonatal terjadi di akhir kehamilan (> 20 minggu). Anemia sedang/berat yang dicatat setiap saat selama kehamilan meningkatkan risiko kematian neonatal dan BBLR. Pertumbuhan janin yang cepat terjadi pada trimester ketiga, meningkatkan kebutuhan akan zat besi dan mikronutrien lainnya. ${ }^{13,16-18}$

\section{Metodologi}

Jenis penelitian yang digunakan adalah penelitian uji analitik yang bersifat case control. Penelitian ini menggunakan randomisasi terhadap pasien ibu hamil dan ibu hamil dengan kurang energi kalori (KEK) pada Kecamatan Sukomanunggal. Penelitian ini bertujuan untuk menganalisis perbedaan antara kadar besi, ferritin, dan transferin pada ibu hamil normal dan ibu hamil dengan KEK.

Populasi penelitian adalah ibu hamil di Kecamatan Sukomanunggal pada trimester 2. Ibu hamil KEK dan ibu hamil normal yang didata di kecamatan kemudian dilakukan pemilihan sampel 
secara random sampling, sesuai dengan besar sampel yang diperlukan. Randomisasi menggunakan labeling pasien-pasien ibu hamil KEK dan ibu hamil normal. Penghitungan besar sampel menggunakan rumus lameshow, didapatkan besar sampel adalah 9, dengan kriteria eksklusi $10 \%$ maka dibulatkan menjadi 10, kemudian perlu 2 kelompok, maka total besar sampel adalah 20 pasien ibu hamil (10 ibu hamil normal dan $10 \mathrm{ibu}$ hamil KEK).

Kriteria inklusi dari penelitian ini adalah ibu hamil trimester kedua dengan kriteria hamil normal tanpa komplikasi kehamilan dan ibu hamil dengan KEK. Ibu hamil KEK dikategorikan berdasarkan ukuran lingkar lengan atas $(<23,5 \mathrm{~cm})$. Kriteria eksklusi adalah pasien hamil di luar trimester 2 dan sudah pernah dilakukan intervensi terhadap KEK. Satuan pengukuran untuk zat besi serum adalah $\mu \mathrm{g} / \mathrm{dl}$, ferritin adalah $\mathrm{mcg} / \mathrm{L}$, dan transferrin adalah $\mathrm{mg} / \mathrm{dL}$.

Variabel bebas pada penelitian ini adalah ibu hamil dengan kurang energi kalori, variabel terikatnya adalah kadar besi serum, ferritin, dan transferin. Waktu dan tempat penelitian adalah Februari - Mei 2020, dan tempat penelitian adalah Kecamatan Sukomanunggal. Penelitian sudah mendapatkan surat kelaikan etik dengan nomor 093/EC/KEPK-FKUC/V/2021.

Tabel 1. Analisis Deskriptif Karakteristik Pasien

\begin{tabular}{lcccc}
\hline No. & Deskriptif & $\begin{array}{c}\text { Kelompok Kasus } \\
\text { (KEK) } \\
\text { Mean } \pm \text { Std. Deviation }\end{array}$ & $\begin{array}{c}\text { Kelompok Normal } \\
\text { Mean } \pm \text { Std. Deviation }\end{array}$ & p value \\
\hline 1. & Usia Ibu & $26,920 \pm 5,316$ & $25,500 \pm 5,179$ & $\mathbf{0 , 5 1 5}$ \\
2. & Usia Kehamilan & $23,500 \pm 1,087$ & $23,920 \pm 1,240$ & $\mathbf{0 , 3 9 1}$ \\
3. & Berat Badan & $52,250 \pm 5,987$ & $63,500 \pm 8,085$ & $\mathbf{0 , 0 0 2}$ \\
4. & Tinggi Badan & $153,250 \pm 4,351$ & $152,670 \pm 3,869$ & $\mathbf{0 , 7 3 2}$ \\
5. & BMI & $22,250 \pm 2,514$ & $27,241 \pm 3,218$ & $\mathbf{0 , 2 7 8}$ \\
6. & LILA & $20,250 \pm 0,829$ & $27,000 \pm 1,5811$ & $<\mathbf{0 , 0 0 0 1}$ \\
\hline
\end{tabular}

\section{Hasil}

Pada penelitian ini dilakukan identifikasi awal pada karakteristik sampel penelitian. Variabel usia ibu, antara kelompok KEK dan kontrol didapatkan $(26,92 \pm 5,316$ vs $25,50 \pm 5,179 ; p=0,515)$, yang berarti tidak terdapat perbedaan antara usia ibu hamil pada pasien KEK dan ibu hamil normal. Variabel usia kehamilan juga dilakukan perbandingan dengan hasil $(23,50 \pm 1,087$ vs 23,92 $\pm 1,240 ; \mathrm{p}=0,391)$ yang berarti tidak terdapat perbedaan antara usia kehamilan pada kelompok kasus dan kontrol. Variabel berat badan terdapat hasil $(52,25 \pm 5,987$ vs $63,50 \pm 8,085 ; p=0.002)$, dengan hasil terdapat perbedaan antara variabel berat badan pada kelompok kasus dan kontrol. Variabel tinggi badan $(153,25 \pm 4,351$ vs $152,67 \pm$ $3,869 ; \mathrm{p}=0,732)$ dengan hasil tidak terdapat perbedaan antara tinggi badan dari kedua kelompok penelitian. Variabel BMI menunjukkan hasil $(22,2500 \pm 2,515$ vs $27,242 \pm 3,218$; $\mathrm{p}=$ 0,278 ) dengan hasil tidak terdapat hubungan antara BMI kedua kelompok penelitian. Variabel LILA menunjukkan hasil $(20,25 \pm 0,829$ vs $27 \pm 1,581$; $\mathrm{p}<0,0001)$ di mana terdapat perbedaan antara hamil normal dan hamil KEK (Tabel 1).

Gambar 1 menunjukkan evaluasi data paritas ibu hamil dan didapatkan ibu hamil dengan paritas 1 terdapat 7 sampel (29\%), ibu hamil dengan paritas 2 terdapat 11 sampel (46\%), ibu hamil dengan paritas 3 terdapat 4 sampel (17\%) dan ibu hamil dengan paritas 4 terdapat 2 sampel (8\%).

Analisis hasil laboratarium pada tabel 2 menunjukan bahwa kadar Hemoglobin ( $\mathrm{Hb}$ ) $(10,500 \pm 2,210$ vs $10,300 \pm 1,144 ; p=0,010)$, hasil ini menunjukan bahwa terdapat perbedaan antara kadar hemoglobin dari kedua kelompok. Kadar eritrosit dengan hasil $(4,067 \pm 0,836$ vs $4,411 \pm 0,822 ; p=0,048$ ) menunjukkan perbedaan yang bermakna antara kedua kelompok, variabel kadar besi pada penelitian ini dengan hasil $(101,301 \pm 40,155$ vs $107,001 \pm 33,686, p=0,255)$, menunjukkan tidak ada perbedaan antara kedua kelompok penelitian. Variabel transferin $(419,170$ $\pm 86,755$ vs $458,830 \pm 68,816, p=0,703)$ menunjukkan hasil tidak ada perbedaan antara kedua kelompok penelitian. Variabel feritin 
$(21,502 \pm 14,400$ vs $26,455 \pm 23,632, p=0,012)$ menunjukkan terdapat perbedaan antara kedua kelompok penelitian.

\section{Analisis Hubungan Albumin dengan LILA}

Pada analisis hubungan albumin dengan ukuran lingkar lengan atas didapatkan nilai $\mathrm{p}=$ 0,197 dan $r=0,273$ (Tabel 3). Hal ini menunjukkan bahwa tidak terdapat hubungan antara kadar albumin dengan LILA

\section{Analisis Hubungan Hb dengan Kadar Besi Serum}

Pada analisis hubungan Hemoglobin dengan kadar besi serum didapatkan nilai $\mathrm{p}=0,005$ dan nilai $r=0,555$ (Tabel 4). Hal ini menunjukkan bahwa terdapat hubungan antara kadar Hb dengan kadar besi serum, di mana terjadi hubungan korelasi yang positif. Hubungan korelasi positif ini menunjukkan bahwa peningkatan kadar besi serum akan menyebabkan peningkatan kadar $\mathrm{Hb}$ pada seorang ibu hamil.

Tabel 2. Analisis Deskriptif Data Laboratorium Pasien

\begin{tabular}{ccccc}
\hline No. & Deskriptif & $\begin{array}{c}\text { Kelompok Kasus (KEK) } \\
\text { Mean } \pm \text { Std. Deviation }\end{array}$ & $\begin{array}{c}\text { Kelompok Normal } \\
\text { Mean } \pm \text { Std. Deviation }\end{array}$ & p \\
\hline 1. & HB & $10,500 \pm 2,210$ & $10,300 \pm 1,144$ & 0,010 \\
2. & Eritrosit & $4,067 \pm 0,836$ & $4,411 \pm 0,822$ & 0,048 \\
3. & Albumin & $4,258 \pm 0,414$ & $4,575 \pm 0,486$ & 0,018 \\
4. & Besi & $101,301 \pm 40,155$ & $107,001 \pm 33,686$ & 0,255 \\
$\mathbf{5 .}$ & Transferin & $419,170 \pm 86,755$ & $458,830 \pm 68,816$ & 0,703 \\
6. & Feritin & $21,502 \pm 14,400$ & $26,455 \pm 23,632$ & 0,012 \\
\hline
\end{tabular}

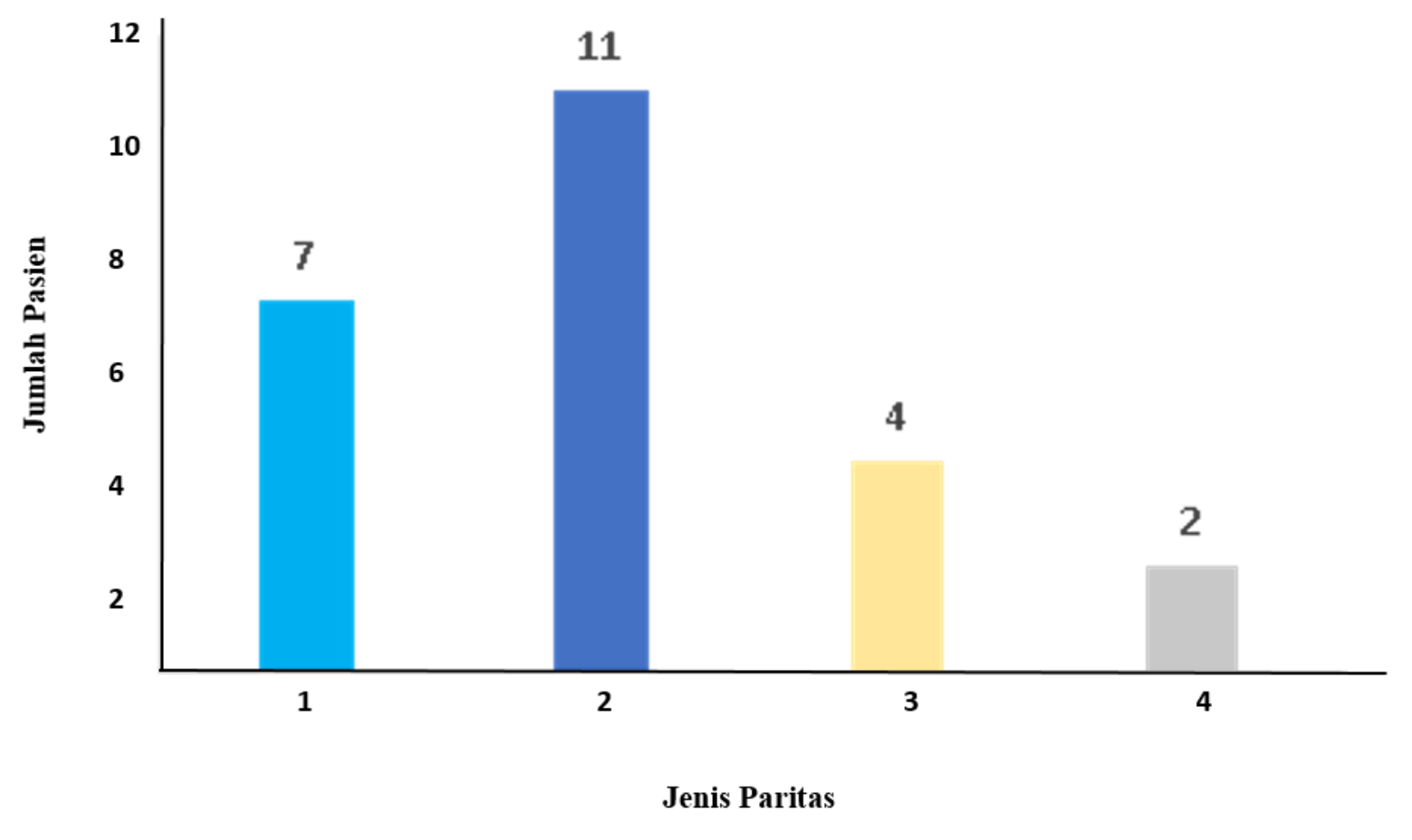

Gambar 1. Data Paritas Pasien 


\section{Analisis Hubungan Hb dengan Transferin}

Pada analisis hubungan hemoglobin dengan transferin didapatkan nilai $\mathrm{p}=0,009$ dan nilai $\mathrm{r}=$ 0,522 (Tabel 5). Hal ini menunjukkan bahwa terdapat hubungan antara kadar hemoglobin dengan kadar besi serum, di mana terjadi hubungan korelasi yang negatif. Hubungan korelasi negatif ini menunjukan bahwa peningkatan kadar transferin akan menyebabkan penurunan kadar $\mathrm{Hb}$ pada seorang ibu hamil.

\section{Analisis Hubungan Hb dengan Feritin}

Pada analisis hubungan $\mathrm{Hb}$ dengan feritin (Tabel 6) didapatkan nilai $p<0,0001$ dan nilai $r=0,855$. Hal ini menunjukkan bahwa terdapat hubungan antara kadar $\mathrm{Hb}$ dengan feritin, di mana terjadi hubungan korelasi yang positif. Hubungan korelasi positif ini menunjukan bahwa peningkatan kadar feritin akan menyebabkan peningkatan kuat kadar $\mathrm{Hb}$ pada seorang perempuan hamil $(85 \%)$.

Tabel 3. Hubungan Albumin dengan LILA

\begin{tabular}{ccccc}
\hline & Kasus & Kontrol & $\mathbf{p}$ & \\
\cline { 1 - 3 } Albumin & $4,258 \pm 0,414$ & $4,575 \pm 0,4864$ & $\mathrm{p}=0,018$ & $\mathbf{p = 0 , 1 9 7}$ \\
LILA & $20,250 \pm 0,829$ & $27,001 \pm 1,581$ & $\mathrm{p}=0,010$ & $\mathbf{r = 0 , 2 7 3}$ \\
\hline
\end{tabular}

Tabel 4. Hubungan Hemoglobin dengan Kadar Besi Serum

\begin{tabular}{|c|c|c|c|c|}
\hline & Kasus & Kontrol & & \\
\hline Kadar Besi Serum & $\begin{array}{c}11,301 \pm 1,144 \\
101,301 \pm 40,155\end{array}$ & $\begin{array}{c}10,501 \pm 2,210 \\
26,455 \pm 23,632\end{array}$ & $\begin{array}{l}p=0,010 \\
p=0,255\end{array}$ & $\begin{array}{l}p=0,005 \\
r=0,555\end{array}$ \\
\hline
\end{tabular}

Tabel 5. Hubungan Hb dengan Transferin

\begin{tabular}{|c|c|c|c|c|}
\hline & Kasus & Kontrol & & \\
\hline Hb & $11,301 \pm 1,144$ & $10,500 \pm 2,210$ & $\mathrm{p}=0,010$ & $p=0,009$ \\
\hline Transferin & $419,170 \pm 86.755$ & $458,830 \pm 68,816$ & $p=0,703$ & $r=-0,522$ \\
\hline
\end{tabular}

Tabel 6. Hubungan Hb dengan Feritin

\begin{tabular}{|c|c|c|c|c|}
\hline & Kasus & Kontrol & & \\
\hline $\mathbf{H b}$ & $11,301 \pm 1,144$ & $10,501 \pm 2,2103$ & $\mathrm{p}=0,010$ & $\begin{array}{l}\mathrm{p}<\mathbf{0 , 0 0 0 1} \\
\mathbf{r}=\mathbf{0 , 8 5 5}\end{array}$ \\
\hline Ferritin & $21,502 \pm 14,401$ & $107,001 \pm 33,686$ & $\mathrm{p}=0,012$ & \\
\hline
\end{tabular}

\section{Pembahasan}

Penelitian ini dilakukan untuk mengetahui perbandingan kadar besi serum, transferin, dan feritin pada pasien hamil normal dengan hamil KEK, mengetahui hubungan albumin dengan lingkar lengan atas, hubungan $\mathrm{Hb}$ dengan kadar besi serum, hubungan $\mathrm{Hb}$ dengan transferin dan hubungan $\mathrm{Hb}$ dengan feritin. Berdasarkan karateristik pasien dengan nilai mean (usia ibu, usia kehamilan, berat badan, tinggi badan, BMI dan lingkar lengan atas), di mana tidak ditemukan perbedaan yang bermakna pada usia $(p=0,515)$, usia kehamilan $(p=0,391)$, tinggi badan $(p=$ $0,732)$ dan BMI $(p=0,278)$ ibu hamil normal dengan ibu hamil KEK, hal ini menunjukan bahwa sampel pada penelitian ini bersifat homogen. Pada analisis hasil laboratorium tidak ditemukan perbedaan yang bermakna antara ibu hamil dan KEK pada kadar besi serum $(\mathrm{p}=0,255)$ dan transferin $(\mathrm{p}=0,703)$. Perbedaan bermakna ditemukan pada kadar $\mathrm{Hb}(\mathrm{p}=0,010)$, eritrosit $(\mathrm{p}=$ $0,048)$, albumin $(\mathrm{p}=0,018)$ dan feritin $(\mathrm{p}=0,012)$. 
Pada analisis perbandingan kadar besi pada ibu hamil normal dengan ibu hamil KEK yang telah kami lakukan, didapatkan hasil $\mathrm{p}=0,710$ yang menunjukan bahwa pada kedua kelompok baik hamil normal dan hamil KEK tidak ditemukan adanya perbedaan. Analisis perbandingan transferin dan feritin yang kami lakukan tidak menunjukan perbedaan antara ibu hamil normal dengan hamil KEK.

Penelitian ini melakukan analisis hubungan albumin dengan lingkar lengan atas, di mana analisis hubungan ini belum pernah dilakukan pada penelitian-penelitian sebelumnya. Analisis hubungan albumin dengan LILA didapatkan hasil $\mathrm{p}=0,197$, menunjukkan bahwa tidak ditemukan hubungan, sehingga ukuran LILA tidak memengaruhi kadar albumin ibu hamil.

Penelitian ini juga menganalisis hubungan $\mathrm{Hb}$ dengan kadar besi serum, yang menunjukkan suatu hubungan yang positif, yang berarti apabila terjadi peningkatan atau penurunan $\mathrm{Hb}$ maka kadar besi serum juga mengalami peningkatan atau penurunan. Pada penelitian Almaratus dan Muniroh (2019) didapatkan hasil yang serupa yaitu hubungan $\mathrm{Hb}$ dengan kadar besi serum sebesar $\mathrm{p}=$ 0,0001 menunjukkan hubungan bermakna dan hubungan yang bersifat positif. ${ }^{19}$

Pada analisis hubungan $\mathrm{Hb}$ dengan transferin pada perempuan hamil KEK dan hamil normal didapatkan hubungan antara kedua variabel tersebut $(\mathrm{p}=0,009)$, dengan hubungan negatif $(\mathrm{r}=$ $-0,522)$, sehingga saat terjadi peningkatan $\mathrm{Hb}$, maka transferin mengalami penurunan, begitu juga apabila kadar $\mathrm{Hb}$ menurun maka maka transferrin akan meningkat.

Pada analisis hubungan $\mathrm{Hb}$ dengan feritin didapatkan hasil yang berhubungan dengan korelasi positif ( $p<0,0001)$ dan $(r=0,855)$. hal ini menunjukkan saat peningkatan $\mathrm{Hb}$ maka feritin juga mengalami peningkatan dan begitu juga sebaliknya. Hal ini sama dengan penelitian terkait hubungan kadar $\mathrm{Hb}$ dan feritin dengan gambaran konduksi saraf pada anak talasemia Beta mayor yang dilakukan Dewi (2017). ${ }^{20}$

\section{Simpulan}

Penelitian ini menunjukan bahwa pada ibu hamil kurang energi kalori, terdapat perbedaan pada kadar hemoglobin, eritrosit, dan ferritin dengan ibu hamil normal. Perbedaan ini kemudian dianalisis dan ditemukan bahwa penurunan $\mathrm{Hb}$ pada ibu hamil KEK akan menyebabkan penurunan kadar besi, peningkatan transferrin, dan penurunan ferritin. Dengan analisis dari penelitian ini maka perbaikan ibu hamil KEK dapat dilakukan dengan pendekatan perbaikan kadar besinya.

\section{Daftar Pustaka}

1. Azizah A, Adriani M. Tingkat kecukupan energi protein pada ibu hamil trimester pertama dan kejadian kekurangan energi kronis. Media Gizi Indonesia. 2017;12(1):216.

2. Anh Nguyen H. Undernutrition during Pregnancy [Internet]. [dikutip 26 September 2021]. Diunduh dari: www.intechopen.com.

3. Chen YH, Li L, Chen W, Liu ZB, Ma L, Gao $\mathrm{XX}$, et al. Pre-pregnancy underweight and obesity are positively associated with smallfor-gestational-age infants in a Chinese population. Scientific Reports. 2019;9(1).

4. Li C, Zhu N, Zeng L, Dang S, Zhou J, Pei L, et al. Effect of maternal pre-pregnancy underweight and average gestational weight gain on physical growth and intellectual development of early school-aged children. Scientific Reports. 2018;8(1).

5. Girsen AI, Mayo JA, Wallenstein MB, Gould JB, Carmichael SL, Stevenson DK, et al. What factors are related to recurrent preterm birth among underweight women? Journal of Maternal-Fetal and Neonatal Medicine. 2018;31(5):560-6.

6. Shindo R, Aoki M, Yamamoto Y, Misumi T, Miyagi E, Aoki S. Optimal gestational weight gain for underweight pregnant women in Japan. Scientific Reports. 2019;9(1).

7. Tang AM, Chung M, Dong KR, Bahwere P, Bose K, Chakraborty R, et al. Determining a global mid-upper arm circumference cut-off to assess underweight in adults (men and nonpregnant women). Public Health Nutrition. 2020;23(17):3104-13.

8. Badfar G, Shohani M, Soleymani A, Azami M. Maternal anemia during pregnancy and small for gestational age: A systematic review and meta-analysis. Journal of Maternal-Fetal and Neonatal Medicine. 2019;32:1728-34.

9. Sumarmi MS, Puspitasari N, Handajani R. Underweight as a risk factor for iron depletion and iron-deficient erythropoiesis among young women in rural areas of East Java, Indonesia The frequency of DISC1 Leu607Phe gene polymorphism in schizophrenia patients at Dr. Soetomo General Hospital Surabaya view project [Internet]. [dikutip 26 September 2021]. Diunduh

dari: 
https://www.researchgate.net/publication/31 9162191.

10. Means RT. Iron deficiency and iron deficiency anemia: Implications and impact in pregnancy, fetal development, and early childhood parameters. Nutrients. MDPI AG Vol. 12; 2020.

11. Fisher $\mathrm{AL}$, Nemeth E. Iron homeostasis during pregnancy. Am J Clin Nutr. 2017;106(Suppl 6):1567S-1574S.

12. Rahmati S, Delpishe A, Azami M, Ahmadi MRH, Sayehmiri K. Systematic review Maternal Anemia during pregnancy and infant low birth weight: A systematic review and Meta-analysis. Int $\mathbf{J}$ Reprod BioMed. 2017;(3):125-34.

13. Tan J, Qi YN, He GL, Yang HM, Zhang GT, Zou K, et al. Association between maternal weight indicators and iron deficiency anemia during pregnancy: A cohort study. Chinese Medical Journal. 2018;131(21):2566-74.

14. Siahaan SCPT, Henderi H, Pristiwanto DSN, Ester WB, Pratama MFI. Intervensi ibu hamil dengan kurang energi kalori melalui suplementasi mikronutrien di Surabaya tahun 2019. Majalah Kedokteran Andalas. 2021;44(1):17-27.

15. Henderi H, Siahaan SCPT, Kusumah IP, Cahjono H, Tannus FA, et al. Correlation of vitamin $\mathrm{d}$ with ferritin in pregnant mothers chronic energy deficiency of the second trimester. Berkala Kedokteran. 2021:17(2):143-50.

16. Patel A, Prakash AA, Das PK, Gupta S, Pusdekar YV, Hibberd PL. Maternal anemia and underweight as determinants of pregnancy outcomes: Cohort study in eastern rural Maharashtra, India. BMJ Open. 2018;8(8):1-15.

17. Bencaiova $G$, Burkhardt $T$, Breymann C. Anemia - Prevalence and risk factors in pregnancy. European Journal of Internal Medicine. $2012 ; 23(6): 529-33$.

18. Tandon R, Jain A, Malhotra P. Management of iron deficiency anemia in pregnancy in India. Indian Journal of Hematology and Blood Transfusion. 2018;34(2):204-15.

19. Almaratus S C, Muniroh L. Hubungan asupan zat besi, protein, vitamin $\mathrm{C}$ dan pola menstruasi dengan kadar hemoglobin pada remaja putri di SMAN 1 Manyar. Media Gizi Indonesia. 2019;14(2):147-53.

20. Dewi WKK. Hubungan kadar hemoglobin dan ferritin dengan gambaran konduksi saraf pada anak talasemia beta mayor. Neurona. 2017;35(1):52-8. 